\title{
Mesoscale spatial structures of soft-bottom macrozoobenthos communities: effects of physical control and impoverishment
}

\author{
Maria Włodarska-Kowalczuk* , Jan Marcin Węsławski \\ Institute of Oceanology PAS, Powstancow Warszawy 55, PO Box 68, 81-712 Sopot, Poland
}

\begin{abstract}
The recognition of the nature of spatial and temporal variability within ecosystems is crucial for understanding the processes that maintain species diversity and ecological stability. In the present study, mesoscale spatial structures of soft-bottom macrobenthic communities were explored at sites with contrasting disturbance regimes and benthic diversities. Two sites in a glacial Arctic fjord were selected: the Inner site, where sediments are inhabited by an impoverished community composed of a few species resistant to large-scale, chronic physical disturbance by glacial sedimentation, and the Outer site, where diverse fauna is structured by biological interactions among populations of species of different sizes and functional groups. Samples were taken at 6 stations (4 van Veen grabs collected per station) located along a $1 \mathrm{~km}$ transect separated by 0 (samples collected at the same station), 200, 400, 600, 800, and $1000 \mathrm{~m}$. Spatial variation at the Inner site was apparent only in changes in relative abundances among a few numerically dominant species (explored using untransformed data), and the fauna was homogenous with respect to species composition (based on presence/ absence data). The spatial heterogeneity in the Outer site community was evident both in species composition and in relative abundances of dominant species populations. The significant autocorrelation peaks on a correlogram of Bray-Curtis similarities of untransformed data indicated a successive sequence of homogenous patches of a minimum $200 \mathrm{~m}$ radius, separated by $600 \mathrm{~m}$. Spatial patterns of species composition similarity varied among species groups of different mobility: sedentary fauna did not exhibit a mesoscale patchiness, while clear patchiness was documented for motile and discretely motile organisms. The current study demonstrates that the spatial structure of benthic biota is related to the diversity and the perturbation level of the studied communities. It also supports the recommendation for spatial separation of replicate samples in soft-bottom macrobenthic surveys.
\end{abstract}

KEY WORDS: Spatial patterns $\cdot$ Scale $\cdot$ Soft bottom $\cdot$ Macrofauna $\cdot$ Diversity $\cdot$ Disturbance

\section{INTRODUCTION}

The term 'distance similarity decay' was introduced by geographers and was later adopted by macroecologists to define the decrease of similarity between 2 observations as the distance between them increases (Nekola \& White 1999). On smaller scales the relationship between distance and the commonality of species composition in ecosystems is usually not simple or monotonic; instead, hierarchical mosaics of patches of de- creasing size (i.e. areas differing from the surroundings that can be detected at smaller scales nesting within patches detectable at larger scales) are observed (Kotliar \& Wiens 1990). The recognition of the nature of spatial and temporal variability within ecosystems is crucial for understanding the processes that maintain species diversity and ecological stability (Legendre \& Fortin 1989). The spatial variability of natural communities also has significant practical implications. The rate of similarity decay is of crucial impor- 
tance for sampling procedures and statistical analyses of ecological data: autocorrelation of data (significant relationships between the measured value and the positions of the stations) can result in the inaccurate estimation of variance among replicates if sampling stations are too close together (Somerfield \& Gage 2000).

In the marine benthic ecological literature 2 aspects of species distribution are often referred to as 'spatial variability': (1) intensity of spatial patterns within a group of samples collected in a particular area (but without reference to the exact positioning of stations) explored with use of mean:variance relationships for univariate measures or by index of multivariate dispersion (IMD) for multivariate data (Warwick \& Clarke 1993) and (2) spatial structure, i.e. how species and communities are distributed in space, taking the geographical positions of the stations into account and exploring how measures vary with distance between samples (Somerfield \& Gage 2000). The intensity of spatial patterns has often been reported as one of the possible indicators of benthic disturbance (e.g. Warwick \& Clarke 1993, WłodarskaKowalczuk et al. 2005), while the issue of the relationship between (1) the benthic community spatial structure and (2) the species richness and perturbation level of the community has not been addressed.

A substantial number of articles address the spatial distribution patterns of individual species on different scales, while comparatively few studies explore the spatial structure of whole benthic communities (Kendall \& Widdicombe 1999, Somerfield \& Gage 2000). Heterogeneity in the distribution of benthic species has usually been ascribed to spatial heterogeneity in physical environmental settings, most often to bottom substrate characteristics (e.g. variability in sediment grain size composition) or the occurrence of small-scale seafloor morphological features that form the so-called 'benthoscape' (Zajac 1999). Benthoscape structures, as well as the faunal variability, can be studied at different scales and were classified by Zajac (1999) into (1) large-scale (i.e. tens of $\mathrm{km}^{2}$ ), (2) mesoscale (hundreds of $\mathrm{m}^{2}$ to $\mathrm{km}^{2}$ ) and (3) small-scale (tens of $\mathrm{m}^{2}$ and less) phenomena. That spatial configurations of particular species distributions can be related to behavioral and functional characteristics has been shown on a small scale by Reise (1979). Spatial patterns of species distribution are produced by an interplay of spatial and temporal environmental variability as well as biological processes and can be modified by natural and anthropogenic disturbances (Caswell \& Cohen 1991); thus, a mosaic of biological patches can form even in areas that are homogenous in terms of basic physical characteristics. Kendall \& Widdicombe (1999), Somerfield \& Gage (2000), and Parry et al. (2003) described the spatial structure of macro- and megabenthic communities within patches of apparently homogenous sediments.
The present study was conducted in a west Spitsbergen glaciated fjord (Hornsund). Previous studies in similar areas documented clear differences in both the physical regimes and benthic communities of the inner and outer fjordic basins. In the outer basins the low level of physical disturbance results in the development of a biologically accommodated, diverse community composed of animals from a wide range of size and functional groups, presumably exploiting a range of resource niches and creating complex food webs (Syvitski et al. 1987, Włodarska-Kowalczuk et al. 2005). In the glacier-proximal inner basins the physically controlled and impoverished benthic community consists of only a few species belonging to 1 functional guild (usually small, motile detritus-feeders) and well adapted to resist disturbance (Włodarska-Kowalczuk et al. 1998, Włodarska-Kowalczuk \& Pearson 2004). Kendall et al. (2003) reported the very homogenous distribution of benthic species in the glacier-proximal, inner basin of Kongsfjord (Spitsbergen). In the current study, 2 sites were selected that had contrasting disturbance regimes and different benthic characteristics (highly diverse/undisturbed outer fjord and impoverished/physically controlled inner fjord) to explore the patterns of change of among sample similarity as the distance separating the geographical locations of the samples increased. We were also interested to see if differences in spatial configurations of species of different functional traits (observed for individual species, e.g. by Reise 1979) would be expressed in multivariate patterns produced by groups of species. We focused on meso-scale (according to the classification of Zajac 1999) spatial structures and hypothesized that: (1) the spatial heterogeneity of macrobenthic composition will be more evident in a biologically accommodated/diverse outerfjord community and (2) spatial structure will vary among groups of species of different mobility.

\section{MATERIALS AND METHODS}

Study area. Hornsund is a wide, open (no sill) fjord located on the southwest coast of Spitsbergen (at 76 to $77^{\circ} \mathrm{N}$ ). Despite its high northern location, the western coast of Spitsbergen has a relatively warm Atlantic character due to the influence of the West Spitsbergen Current, an extension of the North Atlantic Current. The banks of the Hornsund inner basin, Brepollen, are almost entirely formed by the cliffs of 5 tidal glaciers (Storbreen, Hornbreen, Svalisbreen, Mendelejevbreen and Chomjakovbreen). The glacial or glaciofluvial inflows transport large amounts of mineral suspensions and produce steep gradients of water turbidity and mineral sedimentation along the fjord axis. The fjordic 
sediments are composed of glacio-marine deposits, which are mostly silt and clay (M. Zajączkowski pers. comm.). The sediment accumulation rate in Brepollen can reach $35 \mathrm{~cm} \mathrm{yr}^{-1}$, while in the outer parts of Hornsund it is as low as $0.1 \mathrm{~cm} \mathrm{yr}^{-1}$ (Görlich et al. 1987). Longer persistence of fast ice cover and high water turbidity in the inner basins of Hornsund reduces primary production in the water column, and organic matter sedimenting to the bottom is diluted by the high inorganic sediment load (Görlich et al. 1987).

Sampling and laboratory analyses. Sampling took place in July 2005 from aboard the RV 'Oceania'. Two localities were selected for sampling (Fig. 1): (1) Inner, located in Brepollen, a glacial bay at the fjord head $\left(15.34^{\circ} \mathrm{E}, 76.55^{\circ} \mathrm{N}\right)$, and (2) Outer, located at the fjord entrance near the southern bank of the fjord $\left(16.30^{\circ} \mathrm{E}\right.$, $\left.77.01^{\circ} \mathrm{N}\right)$. The selected sampling areas were as uniform as possible with regard to both sediment granulometry and depth. At each locality, samples were taken at 6 stations positioned along a $1 \mathrm{~km}$ transect. The neighboring stations were separated by $200 \mathrm{~m}$. At each station 4 samples were collected using a van Veen grab $\left(0.1 \mathrm{~m}^{2}\right)$. Thus, a hierarchical structure of the spatial distribution of samples was achieved: there were a number of sample pairs separated by 0 (collected at the same station), 200, 400, 600, 800 and $1000 \mathrm{~m}$. Of course, the samples collected at the same station were not separated by exactly $0 \mathrm{~m}$. The ship was positioned at a certain point and replicate grabs were collected. Samples collected in this way were separated by a few meters, but to simplify the presentation of results we named them as 'separated by $0 \mathrm{~m}$ '. The scale of sampling in each locality was defined by a

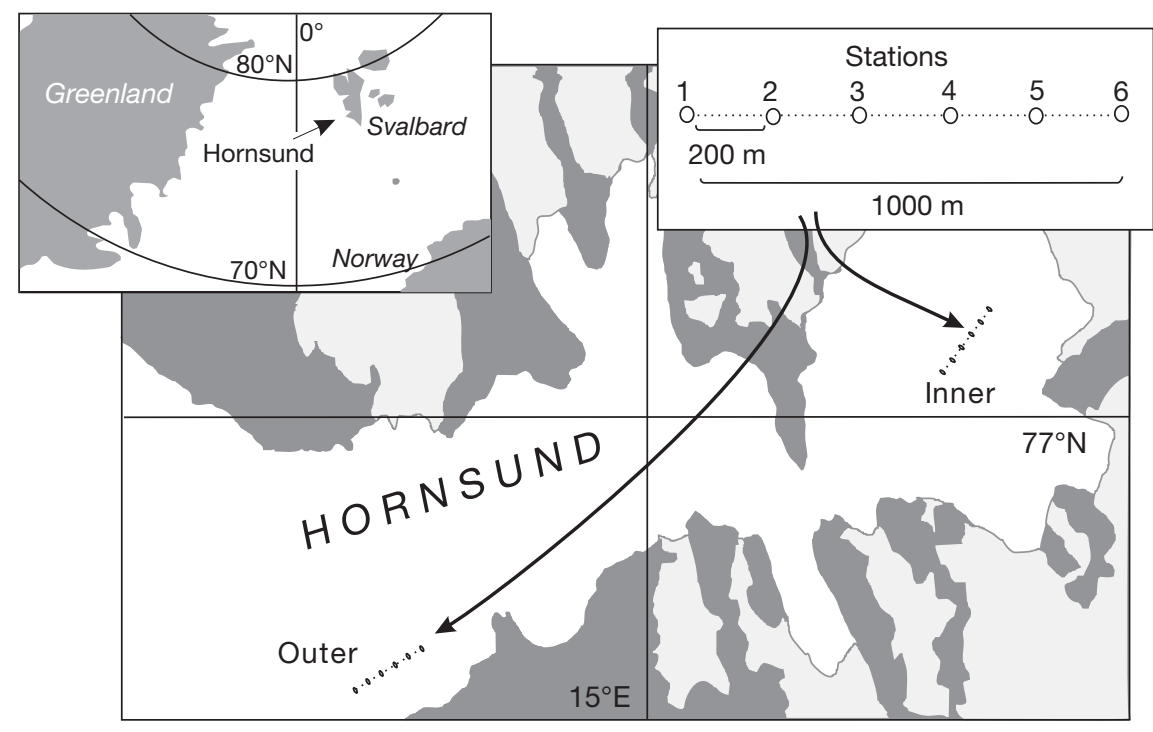

Fig. 1. Spatial configuration of sampling stations on transects and location of the 2 transects (Inner and Outer) in Hornsund. Light grey areas indicate glaciers grain of $0.1 \mathrm{~m}^{2}$, a lag of $200 \mathrm{~m}$ and an extent of $1000 \mathrm{~m}$ (after the terminology of Thrush et al. 1999). Station depths varied from 100 to $120 \mathrm{~m}$ on the Inner transect and from 100 to $115 \mathrm{~m}$ on the Outer transect. The sediment samples for granulomeric and total organic carbon (TOC) content analyses were taken at each station with a box-corer. At both sites the sediments were composed mostly of silt and clay fractions $(<0.0063 \mathrm{~mm})$ with sand admixtures varying from 1.4 to $2.9 \%$ at the Inner site and from 6.8 to $15.1 \%$ at the Outer site (W. Szczuciński unpubl. data). The TOC content in the sediments ranged from 1.83 to $1.89 \%$ at the Inner site and from 1.61 to $1.84 \%$ at the Outer site (W. Szczuciński \& G. Schetter unpubl. data). The van Veen grab was lowered gently to the sea bottom to minimize the bow-wave, which can wash away the surficial sediments (Blomqvist 1991). Recovered sediments were sieved aboard ship using a $0.5 \mathrm{~mm}$ mesh sieve. The samples were fixed in formalin aboard ship, and all the animals were sorted, identified to the lowest possible taxonomic level and enumerated in the laboratory. All the samples collected at Stn 4 and 1 sample collected at Stn 5 on the Inner transect were improperly preserved and thus excluded from the analyses.

Data analyses. The diversity of the 2 localities was assessed on sample and whole-transect scales. Sample diversity was expressed by the number of species $(S)$ per sample and by the Hurlbert rarefaction index $\left(E S_{[n]}\right)$, an estimate of the number of species in a subsample of $n$ individuals, which was developed to facilitate comparisons of the sample diversity comprised of different numbers of individuals (Hurlbert 1971). The $E S_{[\mathrm{n}]}$ was calculated for $\mathrm{n}=100$. Differences in sample density $(D), S$, and $E S_{[100]}$ between 2 locations were identified using 1-way ANOVA. The normality of distribution was tested with the Shapiro-Wilks test and the homogeneity of variance with the Brown-Forsyth test.

Species accumulation curves described the number of observed species $\left(S_{\text {obs }}\right)$ as a function of the number of samples. They permitted the comparison of the diversity of faunal assemblages at comparable levels of sampling effort. Species accumulation curves with $95 \%$ confidence intervals (CI) were computed using the formulae by Colwell et al. (2004). The computation of CI allowed for the statistical comparison of species richness of 2 data sets, i.e. the differences were not significant at $\mathrm{p}<0.05$ if the $95 \% \mathrm{CI}$ overlapped (Colwell et al. 2004). 
Frequency of occurrence (percentage of samples in which a species was found in the total number of samples) and dominance (percentage of individuals of a particular species in the total number of all animals found in all samples) were calculated for all species at each site. The diversity of functional groups (guilds) was also described. All species were classified by their feeding mode and comparative mobility according to Fauchald \& Jumars (1979), Feder \& Matheke (1980), Kuznetsov (1980) and other publications and unpublished observations. Following Fauchald \& Jumars (1979), guilds representing combinations of 5 feeding types (carnivores, herbivores, suspension-feeders, surface detritus-feeders and subsurface detritus-feeders, or burrowers) and 3 mobility types (sessile, discretely motile and motile) were considered. The number of guilds and percentage of each functional group in the total number of organisms at each site was calculated.

The BIO-ENV procedure was applied to examine the relationship between biotic data and environmental factors including depth, sand (fraction $>0.063 \mathrm{~mm}$ ) and TOC content in sediments. The environmental data were normalized prior to the analysis. The Spearman rank correlation $\left(\mathrm{R}_{\mathrm{S}}\right)$ was calculated between the biotic Bray-Curtis similarity matrix and abiotic matrices including all possible combinations of the considered environmental factors (Clarke \& Warwick 1994).

The Bray-Curtis index was used to explore the patterns of spatial configurations along the transects. The biotic similarity among samples was calculated using: (1) untransformed data and (2) presence/absence data. The analyses of presence/absence data describe patterns in species composition. The Bray-Curtis index computed on untransformed species abundance data reflects similarities in the abundance of dominant species and strongly underestimates the importance of less abundant species (Clarke \& Warwick 1994). The BrayCurtis similarities were calculated for both untransformed and presence/absence data for each sample pair within a transect. In addition to sample similarity matrices, a matrix containing spatial distances separating each sample pair was constructed.

Spatial autocorrelation analysis, in which measures of spatial distance are a part of the analysis, was applied to analyze spatial configurations of biotic similarities. Relationships between the similarities and spatial separation of samples was examined using $R_{\mathrm{S}}$ computed between corresponding elements of the biotic similarity and spatial distance matrices (Somerfield \& Gage 2000). Correlation significance was determined with a Monte Carlo permutation procedure using the RELATE routine of the PRIMER program (Clarke \& Warwick 1994). The spatial patterns of biotic similarities were explored using multivariate correlograms. Biotic similarities within sample groups separated by the same distance were compared to the similarities of all other samples. The relationships between the similarity matrix and 'model' matrices were tested with $\mathrm{R}_{\mathrm{S}}$. 'Model' matrices were created by coding the sample similarities separated by the relevant distance as 1 and all the other similarities as 0 . The computed correlation coefficients were plotted against the relevant spatial distances (Somerfield \& Gage 2000). Significant positive autocorrelation occurred when $\mathrm{p}<0.025$, while significant negative autocorrelation occurred when $\mathrm{p}>$ 0.975 (Somerfield \& Gage 2000). The alternation of positive and negative autocorrelation values were an indication of patchiness (Legendre \& Fortin 1989). The significant autocorrelation minimum on a correlogram was used to indicate the extent of a patch of similar fauna (Legendre \& Fortin 1989). If a significant autocorrelation maximum was detected at a sample separation distance larger than that of the minimum, then the distance between patches of similar composition were defined (Legendre \& Fortin 1989, Parry et al. 2003). The last correlation coefficient was not interpreted because it was based on too few pairs of samples (Legendre \& Fortin 1989).

The analyses of spatial patterns (as described above) of species composition (examined using the BrayCurtis index of similarity of presence/absence data) were conducted separately for different mobility groups at the 2 transects. Three mobility types were considered: (1) sedentary, no post-settlement movement, (2) discretely motile, stationary during feeding but capable of moving from place to place and (3) motile, feeding while in motion and moving relatively frequently or continuously. Multivariate correlograms were constructed only for discretely motile and motile species on the Outer transect, as only in these cases was the significant correlation between sample similarities and spatial separation documented.

Species accumulation curves and the Bray-Curtis similarities were computed using EstimateS (v. 7.5, R. K. Colwell, available at: purl.oclc.org/estimates). $E S_{\text {[n] }}$ and $\mathrm{R}_{\mathrm{S}}$ were calculated, and the BIO-ENV analysis was conducted, using the PRIMER package.

\section{RESULTS}

\section{Density and diversity of benthic communities}

The mean density $(D)$ of macrofauna was much higher in samples collected on the Outer transect $\left(\right.$ mean $\pm \mathrm{SD}, 913.3 \pm 135.7$ ind $0.1 \mathrm{~m}^{-2}$ ) than on the Inner transect $\left(327.1 \pm 83.9\right.$ ind. $\left.0.1 \mathrm{~m}^{-2}\right)$ (Fig. 2a). There was a significant difference between the number of animals per sample between the 2 localities (1-way ANOVA, $F=271.4, \mathrm{p}<0.0001)$. Similarly, $S$ and 

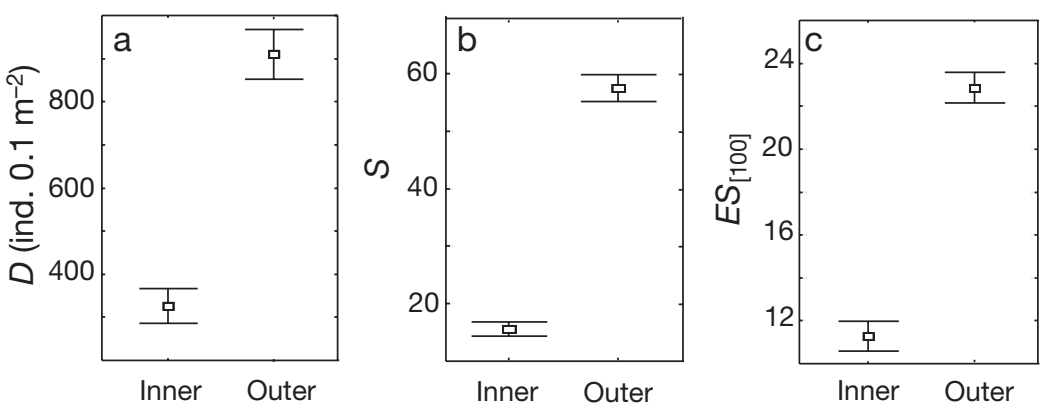

Fig. 2. Mean \pm 0.95 confidence intervals (CI) (a) density $(D)$, (b) number of species per sample $(S)$, and (c) Hurlbert index $\left(E S_{[100]}\right)$ in samples taken on the Inner and Outer transects

$E S_{[100]}$ were significantly higher at the Outer site (mean $\pm \mathrm{SD}, 58.2 \pm 5.4$ and $22.8 \pm 0.8$, respectively) than at the Inner site $(16.3 \pm 2.6$ and $11.3 \pm 1.5$, respectively) (Fig. 2b,c). The significant differences in $S$ and $E S_{[100]}$ were identified using 1-way ANOVA ( $F=941.9$, $\mathrm{p}<0.0001$ and $F=562.5, \mathrm{p}<0.0001$, respectively).

The total observed number of macrobenthic species was 40 at the Inner site and 168 at the Outer site. The species accumulation curve representing the Inner locality stabilized towards asymptotic values, while the Outer curve was quite steep and showed no signs of leveling off (Fig. 3). The Outer curve lay over the Inner curve at all accumulation levels. The $95 \% \mathrm{CI}$ for $S_{\text {obs }}$ never overlapped indicating that there were significant differences between the curves of the 2 sites at $\mathrm{p}<0.05$.

\section{Dominant species, functional groups and relations to environmental factors}

Small, motile detritus-feeding polychaetes of 2 species, Aphelochaeta sp. and Cossura longocirrata, made up more than $80 \%$ of all animals collected in samples from

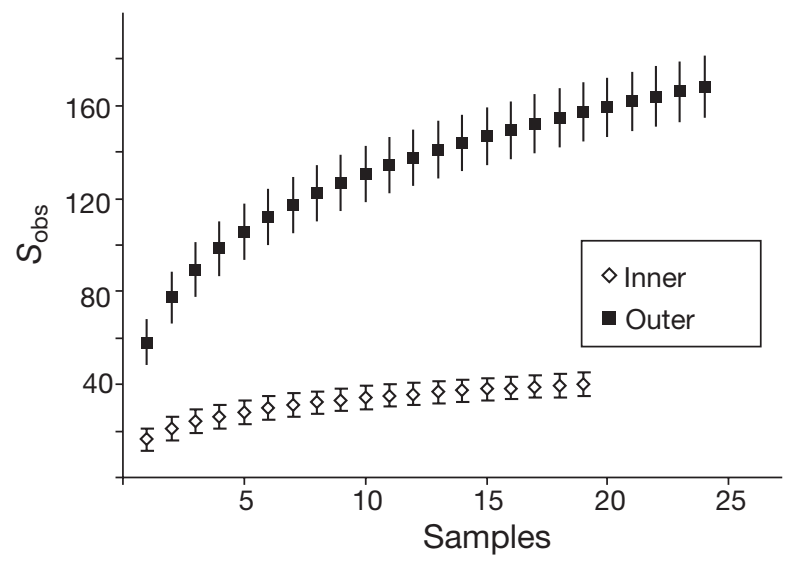

Fig. 3. Species accumulation curves for the Inner and Outer transects. The curves are plotted along with $95 \%$ CI the Inner transect (Table 1). Those 2 species were also abundant on the Outer transect but were accompanied by large numbers of the carnivorous polychaete Lumbrineris sp. and tube-building polychaetes Apistobranchus tulbergi and Maldane sarsi, discretely motile and sedentary, respectively (Table 1).

Five functional groups were found in the Inner transect samples (Table 2). Motile detritus-feeders (either surface or subsurface) made up almost $90 \%$ of all animals collected at this site. On the Outer transect, 12 functional groups were discriminated (Table 2). Motile surface detritusfeeders made up $44 \%$ of all animals. The distribution of fauna among the other groups was more even than on the Inner transect (Table 2).

The BIO-ENV analysis showed that at both sites the species distribution patterns could not be explained by the environmental variables considered in the present study. The correlations between the individual factors or combinations of factors and the biotic data were very weak (ranging from 0.01 to 0.40 , Table 3 ).

\section{Spatial patterns of whole communities}

No evidence of spatial patterns of similarity estimated with the presence/absence data was observed

Table 1. Dominant species on the Inner and Outer transects. D: dominance; F: frequency of occurrence. Ten most abundant species are presented for each site

\begin{tabular}{|lcr|}
\hline Inner & $\mathrm{D}(\%)$ & $\mathrm{F}(\%)$ \\
\hline Inner & & \\
Aphelochaeta sp. & 51.0 & 100 \\
Cossura longocirrata & 31.4 & 100 \\
Polycirrus arcticus & 3.8 & 100 \\
Chone paucibranchiata & 2.4 & 100 \\
Euchone sp. & 2.3 & 100 \\
Chaetozone setosa & 3.2 & 95 \\
Aglaophamus malmgreni & 1.5 & 100 \\
Heteromastus filiformis & 0.8 & 89 \\
Thyasira dunbari & 0.7 & 63 \\
Levinsenia sp. & 0.4 & 68 \\
Outer & & \\
Aphelochaeta sp. & 31.0 & 100 \\
Lumbrineris sp. & 9.3 & 100 \\
Cossura longocirrata & 8.2 & 100 \\
Apistobranchus tullbergi & 8.1 & 100 \\
Chaetozone setosa & 7.5 & 100 \\
Leitoscoloplos mammosus & 7.3 & 100 \\
Maldane sarsi & 5.9 & 100 \\
Eteone flava/longa & 1.4 & 100 \\
Heteromastus filiformis & 1.4 & 100 \\
Melita formosa & 1.2 & 50 \\
\hline
\end{tabular}


Table 2. Percentages of functional types in total number of animals on the Inner and Outer transects. Functional group codes: first letter/s, feeding type-f: suspension-feeders, $s$ : surface detritus-feeders, b: subsurface detritus-feeders, c: carnivores; last letter, mobility type-m: motile, d: discretely motile, s: sedentary; u: unknown functional type

\begin{tabular}{|lcr|}
\hline Functional group & Inner & Outer \\
\hline $\mathrm{bs}$ & - & 6.1 \\
$\mathrm{sS}$ & - & 2.5 \\
$\mathrm{fs}$ & 2.6 & 0.5 \\
$\mathrm{sd}$ & 4.1 & 8.9 \\
$\mathrm{fd}$ & - & 0.2 \\
$\mathrm{f} / \mathrm{sd}$ & 2.4 & 0.3 \\
$\mathrm{bm}$ & 33.0 & 18.5 \\
$\mathrm{~cm}$ & - & 12.9 \\
$\mathrm{c} / \mathrm{sm}$ & - & 1.4 \\
$\mathrm{sm}$ & 55.4 & 43.7 \\
$\mathrm{fm}$ & - & 0.1 \\
$\mathrm{f} / \mathrm{sm}$ & - & 0.4 \\
$\mathrm{u}$ & 1.5 & 4.6 \\
\hline
\end{tabular}

Table 3. BIO-ENV analysis: Spearman rank correlations $\left(\mathrm{R}_{\mathrm{S}}\right)$ between biotic and abiotic similarity matrices on the Inner and Outer transects. Abiotic matrices include all combinations of environmental variables $(k)$ : sand: $>0.063 \mathrm{~mm}$ fraction of sediment; TOC: total organic carbon in sediment; D: depth. Values in bold indicate the highest correlation

\begin{tabular}{|lcrr|}
\hline \multirow{2}{*}{$k$} & Variable & \multicolumn{2}{c|}{$\mathrm{R}_{\mathrm{S}}$} \\
\cline { 3 - 4 } & & Inner & Outer \\
\hline & Sand & $\mathbf{0 . 4 0}$ & 0.27 \\
& TOC & 0.01 & $\mathbf{0 . 3 9}$ \\
2 & D & -0.01 & -0.24 \\
& Sand, TOC & 0.29 & 0.30 \\
& Sand, D & 0.20 & 0.27 \\
3 & TOC, D & 0.03 & 0.26 \\
& Sand, TOC, D & 0.20 & 0.31 \\
\hline
\end{tabular}

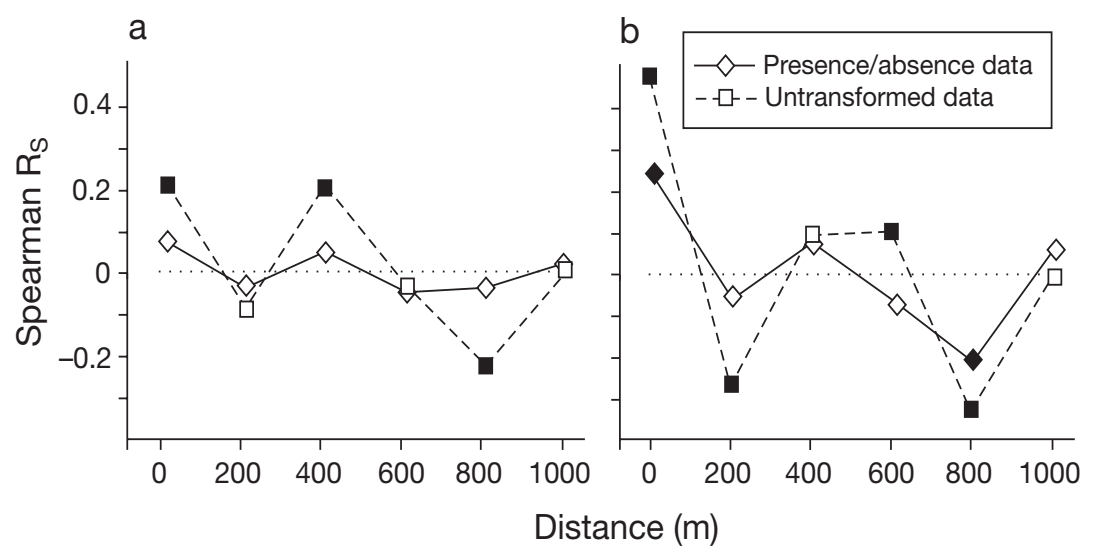

Fig. 4. Multivariate correlograms produced for Bray-Curtis similarities computed on untransformed and presence/absence data for samples collected on the (a) Inner and (b) Outer transects. Black symbols: significant autocorrelation values $(\mathrm{p}<0.025$ or $\mathrm{p}>0.975)$; white symbols: non-significant values $(0.025<\mathrm{p}<0.975)$ along the Inner transect. The spatial autocorrelation analyses between similarity and spatial distance matrices showed a homogenous distribution of species. The significant negative autocorrelation of Bray-Curtis similarity of untransformed data at the Inner transect occurred at a distance of $800 \mathrm{~m}$ indicating the possible presence of patches with a minimum radius of $800 \mathrm{~m}$ (Fig. 4).

Spatial patterns of similarity of untransformed data were evident along the Outer transect, although the relationship between similarity and distance was not simple or monotonic. The multivariate correlograms showed that the studied spatial patterns were patchy. On the correlogram of BrayCurtis similarities of untransformed data at the Outer transect there were 2 significant negative autocorrelation minima, at 200 and $800 \mathrm{~m}$, and 1 autocorrelation maximum. This may indicate a sequence of patches, homogenous patches of a minimum radius of $200 \mathrm{~m}$ and successive patches of similar composition separated by $600 \mathrm{~m}$. One significant negative autocorrelation minimum at $800 \mathrm{~m}$ was detected on the correlogram of untransformed data at the Outer transect.

\section{Spatial patterns in mobility groups}

Four sedentary, 6 discretely motile and 22 motile species were recorded in samples collected on the Inner transect. Forty sedentary, 14 discretely motile and 93 motile species were found at the Outer locality.

The distribution of species of all mobility groups was homogenous at the Inner site: there was no significant Spearman's correlation between the presence/absence data similarity and distance matrices. In addition, no spatial structures were observed in the distribution of sedentary species at the Outer locality. The spatial configurations of discretely motile and motile species on the Outer transect were very similar. Both groups exhibited positive Spearman correlations of similarity and distance matrices indicating that samples taken close together were more similar than samples collected further apart (Table 4). Significant negative autocorrelation minima at multivariate correlograms indicated the occurrence of patches with a minimum radius of $800 \mathrm{~m}$ in distribution of both motile and discretely motile species (Fig. 5). 
Table 4. Spearman rank correlations $\left(\mathrm{R}_{\mathrm{S}}\right)$ between corresponding elements of sample Bray-Curtis index similarity matrices (based on untransformed and presence/absence data) and sample distance matrices on the Inner and Outer transects. Only presence/absence data were used in the analysis of mobility groups. ${ }^{*} \mathrm{p}<0.05$

\begin{tabular}{|lrrrrr|}
\hline & \multicolumn{2}{c}{ Inner } & \multicolumn{2}{c|}{ Outer } \\
& $\mathrm{R}_{\mathrm{S}}$ & $\mathrm{p}$ & $\mathrm{R}_{\mathrm{S}}$ & $\mathrm{p}$ \\
\hline All species, presence/absence data & 0.044 & 0.243 & 0.192 & $0.007^{*}$ \\
All species, untransformed data & 0.215 & $0.018^{*}$ & 0.257 & $0.004^{*}$ \\
& & & & \\
Sedentary species & -0.126 & 0.989 & -0.003 & 0.504 \\
Discretely motile species & 0.003 & 0.433 & 0.165 & $0.013^{*}$ \\
Motile species & 0.082 & 0.160 & 0.201 & $0.004^{*}$ \\
\hline
\end{tabular}

bergen) (Kendall et al. 2003). The glacier-proximal benthic communities are structured by the chronic physical disturbance produced by the sedimentation of mineral materials transported by glacial melt waters (Włodarska-Kowalczuk et al. 1998, Włodarska-Kowalczuk \& Pearson 2004, Somerfield et al. 2006). Only species resistant to continuous burial by sedimenting mineral particles and able to dwell in unstable, frequently resuspended and redeposited sediments can survive in glacier-proximal areas (Syvitski et al. 1987). The sample species richness was 3-fold lower in the Hornsund glacial bay (Inner locality) than in the Outer locality. The species pool in the glacial bay was very low, as the species accumulation curve started to level off after as few as 10 samples collected. Apparently, there are fewer species available for possible variation among samples in the Inner site community than in the Outer site community. The glacial bay community is impoverished not only in terms of species numbers but also with regard to functional group diversity; the fauna is almost entirely composed of 1 functional group: small, motile detritus-feeders. The biological interactions among species are limited due to the simplicity of the community structure, low densities of benthic populations and overwhelming effects of physical forcing induced by glacial disturbance. When the relation between the disturbance and the spatial heterogeneity of biological communities is studied, the relative scales of both the disturbance and the studied biotic patterns must be considered. Small-scale episodic disturbance events can increase biotic heterogeneity on a larger scale. For example, iceberg scouring of Arctic sediments can create a mosaic of patches of different successional stages following defaunations and, thereby, largely increase spatial heterogeneity on a larger scale (Gutt \& Piepenburg 2003). The disturbance experienced by glacial bay benthic communities is chronic and operates on a bay-wide scale, i.e. several kilometers (Görlich et al. 1987), thus smoothing biological variability on a scale of hundreds of meters.

The spatial heterogeneity in the Outer site community was evident both in species composition and the numbers of dominant species populations. The site species pool and the sample species richness are very high at the Outer site. The outer basins of glacial fjords are inhabited by complex communities composed of animals from a wide range of size and functional types, presumably exploiting more resource niches and creating a complex system of biological interactions (Włodarska-Kowalczuk et al. 2005). For example, the Outer site samples contained large sipunculids Golfin- numbers of dominant species) was also reported glacier-proximal sediments in Kongsfjord (West Spits- 
gia margaritacea, which can influence the spatial variability of infaunal populations through sediment bioturbation (M. Kędra pers. comm.). Kendall \& Widdicombe (1999) studied small-scale spatial patterns in the macrofauna of shallow, subtidal sediments in Plymouth Sound. They suggested that the occurrence and spatial variability of large bioturbating thalanassid shrimps were responsible for the patchiness observed in the spatial configurations of macrobenthic infaunal community at a scale of $500 \mathrm{~m}$ at one of the studied sites. Another site they studied was devoid of large bioturbators, and the infauna was homogenously distributed at scales from $50 \mathrm{~cm}$ to $500 \mathrm{~m}$. The spatial structure of species distributions may be shaped by biological rather than physical factors as was shown by Hewitt et al. (1996), who found the same spatial patterns (in terms of intensity and patch size) of infaunal bivalve distributions at different sites irrespective of the contrasting hydrological regimes and sediment grain sizes.

A simple, monotonic relationship between sample similarity and distance is rarely observed in softbottom macrofauna studied on scales of tens or hundreds of meters (Somerfield \& Gage 2000). Instead, patches of similar composition are formed (Morrisey et al. 1992). The patchiness of single-species distribution was detected at scales of ca. $10 \mathrm{~m}$ for estuarine soft-bottom bivalves (McArdle \& Blackwell 1989) and 5 to $30 \mathrm{~m}$ for intertidal polychaetes and molluscs (Thrush et al. 1989). The spatial variation of selected groups of polychaetes dwelling in subtidal estuarine sediments was evident at scales ranging from $10 \mathrm{~m}$ to $3.5 \mathrm{~km}$ (Morrisey et al. 1992). How, and if, these small-scale, single-species spatial configurations translate into the coarser-scale multivariate spatial patterns of whole communities is not clear. Somerfield \& Gage (2000) showed that strong patterns of aggregation of individual species do not necessarily induce similar patterns in multivariate patterns of the whole community. Multivariate pattern analyses average the patterns of variability of different taxa, which can differ considerably as was shown in, for example, major phyla for kelp holdfast-associated macrofauna (Anderson et al. 2005).

Spatial multivariate variation of undisturbed softbottom benthic macrofaunal communities seems to be evident on scales of hundreds of meters. Gray (2000) reported a $50 \%$ decrease of mean Bray-Curtis similarity of samples over $140 \mathrm{~m}$ and a $75 \%$ decrease over $450 \mathrm{~m}$ in the soft-bottom macrofauna of Norwegian oil fields. Kendall \& Widdicombe (1999) observed a drop in similarity in sample pairs separated by $500 \mathrm{~m}$ (and consistent species composition at smaller scales) in the shallow-water, soft-bottom macrobenthic communities of Plymouth Sound. Patches with a radius of $200 \mathrm{~m}$ were evident in the undisturbed Outer locality in the present study in Hornsund. Patches $2.5 \mathrm{~km}$ in size and of consistent similarities were detected for largebodied, soft-bottom epifauna studied at scales ranging from $600 \mathrm{~m}$ to $50 \mathrm{~km}$ (Stevens 2005). The soft-bottom macrobenthic heterogeneity seems to be less clear when larger scales (i.e. tens of kilometers) are considered. Ellingsen (2001) reported consistent composition of infauna across tens of kilometers on the Norwegian continental shelf and detected only a very weak negative correlation $(R=-0.4)$ between Bray-Curtis similarity and sample distance and no relationship between the distance and the numbers of shared species across distances ranging from 10 to $130 \mathrm{~km}$.

Spatial configuration of animals can be related to their spatial behavior mode (Reise 1979). The relation between mobility and patch size was apparent in the infaunal bivalves studied by Hewitt et al. (1996). We observed different patterns of mesoscale spatial variability in groups of species of different mobility: sedentary fauna was evenly distributed across the range of the present study and showed no sign of spatial aggregation, while clear patchiness was documented for motile and discretely motile organisms. These contrasts indicate the importance of post-settlement processes in setting spatial patterns in soft-bottom communities (see e.g. Olafsson et al. 1994). Motile species can react actively to, for example, the temporal and spatial variability of organic matter supply by burrowing through the sediments or passively migrating with the near-bottom water movements (e.g. Beukema \& de Vlas 1989, Cummings et al. 1995). The distribution of sedentary fauna must be established at a settlement phase and can exhibit random configurations often associated with strong territoriality, as was shown with the tube-dwelling polychaetes by Reise (1979).

The spatial configuration of the fauna must be considered when sampling in order to describe the biotic variability within a given community or region. Spatial autocorrelation, i.e. the relationship between the position in space and the value being measured, can severely bias an accurate estimation of variance of replicates as well as alter the correct number of degrees of freedom in many statistical analyses (Legendre 1993). Our results support the opinion of Somerfield \& Gage (2000) that replicate samples of soft-bottom benthos should be spatially dispersed to avoid autocorrelation pitfalls. The distance separating the samples collected from a ship in a subtidal basin at a single station can vary depending on depth and water movement, but the application of GPS to navigate should limit this variation to a range of a few meters. Somerfield \& Gage (2000) recommended that replicate samples be taken at least $40 \mathrm{~m}$ apart. In undisturbed sediments of 
the Outer site, the samples collected at a single station were much more similar than samples separated by $200 \mathrm{~m}$, and so treating them as replicates can bias subsequent statistical analyses. We strongly recommend spatial separation of replicate samples in routine softbottom macrobenthic studies.

Acknowledgements. We thank colleagues who helped with benthic sampling and sample sieving on board the RV 'Oceania' in Hornsund in July 2005. Polychaetes were identified by $\mathrm{S}$. Gromisz. The research was supported by a grant from the State Committee for Scientific Research, Poland no. PBZKBN-108/P04/2004. The authors acknowledge support from the MarBEF Network of Excellence Marine Biodiversity and Ecosystem Functioning, which is funded by the Sustainable Development, Global Change and Ecosystems Programme of the European Community's Sixth Framework Programme (contract no. GOCE-CT-2003-505446). This publication is contribution number MPS-08011 of MarBEF and a contribution to the MarBEF responsive mode program ArctEco.

\section{LITERATURE CITED}

Anderson MJ, Diebel CE, Blom WM, Landers TJ (2005) Consistency and variation in kelp holdfast assemblages: spatial patterns of biodiversity for the major phyla at different taxonomic resolutions. J Exp Mar Biol Ecol 320:35-56

Beukema JJ, de Vlas J (1989) Tidal-current transport of thread-drifting postlarval juveniles of the bivalve Macoma baltica from the Wadden Sea to the North Sea. Mar Ecol Prog Ser 52:193-200

Blomqvist S (1991) Quantitative sampling of soft-bottom sediments: problems and solutions. Mar Ecol Prog Ser 72:295-304

Caswell H, Cohen JE (1991) Communities in patchy environments: a model of disturbance, competition and heterogeneity. In: Kolasa J, Pickett STA (eds) Ecological heterogeneity. Springer-Verlag, New York

Clarke KR, Warwick RM (1994) Changes in marine communities: an approach to statistical analysis and interpretation. Natural Environment Research Council, Plymouth Marine Laboratory, Plymouth

> Colwell RK, Mao CX, Chang J (2004) Interpolating, extrapolating and comparing incidence-based species accumulation curves. Ecology 85:2717-2727

Cummings VJ, Pridmore RD, Thrush SF, Hewitt JE (1995) Post-settlement movement by intertidal benthic macroinvertebrates: do common New Zealand species drift in the water column? NZ J Mar Freshw Res 29:59-67

Ellingsen KE (2001) Biodiversity of a continental shelf softsediment macrobenthos community. Mar Ecol Prog Ser 218:1-15

Fauchald K, Jumars PA (1979) The diet of worms: a study of polychaete feeding guilds. Oceanogr Mar Biol Annu Rev 17:193-284

Feder HM, Matheke GEM (1980) Subtidal benthos. Port Valdez, Alaska: environmental studies 1976-1979. Institute of Marine Sciences, University of Alaska, Fairbanks, AK

Görlich K, Węsławski JM, Zajaczkowski M (1987) Suspension settling effect on macrobenthos biomass distribution in the Hornsund fjord, Spitsbergen. Polar Res 5:175-192

Gray JS (2000) The measurement of marine species diversity, with an application to the benthic fauna of the Norwegian continental shelf. J Exp Mar Biol Ecol 250:23-49
Gutt J, Piepenburg D (2003) Scale-dependent impact on diversity of Antarctic benthos caused by grounding of icebergs. Mar Ecol Prog Ser 253:77-83

Hewitt JE, Thrush SF, Cummings VJ, Pridmore RD (1996) Matching patterns with processes: predicting the effect of size and mobility on the spatial distributions of the bivalves Macomona liliana and Austrovenus stutchburyi. Mar Ecol Prog Ser 135:57-67

Hurlbert SH (1971) The non-concept of species diversity: a critique and alternative parameters. Ecology 52:577-586

Kendall MA, Widdicombe S (1999) Small-scale patterns in the structure of macrofaunal assemblages of shallow soft sediments. J Exp Mar Biol Ecol 237:127-140

Kendall MA, Widdicombe S, Weslawski JM (2003) A multiscale study of the biodiversity of the benthic infauna of the high-latitude Kongsfjord, Svalbard. Polar Biol 26: 383-388

Kotliar NB, Wiens JA (1990) Multiple scales of patchiness and patch structure: a hierarchical framework for the study of heterogeneity. Oikos 59:253-260

Kuznetsov AP (1980) Ekologia donnyh soobszczestw szelfovyh zon mirowowo okeana. Isdatelstwo 'Nauka', Moskva

- Legendre P (1993) Spatial autocorrelation: trouble or new paradigm? Ecology 74:1659-1673

Legendre P, Fortin MJ (1989) Spatial pattern and ecological analysis. Vegetatio 80:107-138

McArdle BH, Blackwell RG (1989) Measurement of density variability in the bivalve Chione stutchburyi using spatial autocorrelation. Mar Ecol Prog Ser 52:245-252

Morrisey DJ, Howitt L, Underwood AJ, Stark JS (1992) Spatial variation in soft-sediment benthos. Mar Ecol Prog Ser 81:197-204

Nekola JC, White PS (1999) The distance decay of similarity in biogeography and ecology. J Biogeogr 26:867-878

Olafsson EB, Peterson CH, Ambrose WG (1994) Does recruitment limitation structure populations and communities of macro-invertebrates in marine soft sediments: the relative significance of pre- and post-settlement processes. Oceanogr Mar Biol Annu Rev 32:65-109

Parry DM, Kendall MA, Pilgrim DA, Jones MB (2003) Identification of patch structure within marine benthic landscapes using a remotely operated vehicle. J Exp Mar Biol Ecol 285-286:497-511

Reise K (1979) Spatial configurations generated by motile benthic polychaetes. Helgol Wiss Meeresunters 32:55-72

Somerfield PJ, Gage JD (2000) Community structure of the benthos in Scottish sea-lochs. IV. Multivariate spatial pattern. Mar Biol 136:1133-1145

Somerfield PJ, Cochrane SJ, Dahle S, Pearson TH (2006) Free-living nematodes and macrobenthos in a highlatitude glacial fjord. J Exp Mar Biol Ecol 330:284-296

Stevens T (2005) Scales of similarity in soft-sediment epibenthic assemblages: implications for marine protected area design. Mar Biol 146:345-354

Syvitski JPM, Burrell DC, Skei JM (1987) Fjords. Processes and products. Springer-Verlag, New York

Thrush SF, Hewitt JE, Pridmore RD (1989) Patterns in the spatial arrangements of polychaetes and bivalves in intertidal sandflats. Mar Biol 102:529-535

Thrush SF, Lawrie SM, Hewitt JE, Cummings VJ (1999) The problem of scale: uncertainties and implications for softbottom marine communities and the assessment of human impacts. In: Gray JS, Ambrose W, Szaniawska A (eds) Biogeochemical cycling and sediment ecology. Kluwer Academic Publishers, Dordrecht, p 195-210

Warwick RM, Clarke KR (1993) Increased variability as a symptom of stress in marine communities. J Exp Mar Biol Ecol 172:215-226 
Włodarska-Kowalczuk M, Pearson TH (2004) Soft-bottom macrobenthic faunal associations and factors affecting species distributions in an Arctic glacial fjord (Kongsfjord, Spitsbergen). Polar Biol 27:155-167

Włodarska-Kowalczuk M, Weslawski JM, Kotwicki L (1998) Spitsbergen glacial bays macrobenthos - a comparative study. Polar Biol 20:66-73

Włodarska-Kowalczuk M, Pearson TH, Kendall MA (2005)

Editorial responsibility: Otto Kinne,

Oldendorf/Luhe, Germany
Benthic response to chronic natural physical disturbance by glacial sedimentation in an Arctic fjord. Mar Ecol Prog Ser 303:31-41

Zajac RN (1999) Understanding the sea floor landscape in relation to impact assessment and environmental management in coastal marine sediments. In: Gray JS, Ambrose W, Szaniawska A (eds) Biogeochemical cycling and sediment ecology. Kluwer Academic Publishers, Dordrecht, p 211-227

Submitted: July 6, 2007; Accepted: October 17, 2007

Proofs received from author(s): March 2, 2008 